The volumes are well printed and on good thick paper ; the price is very high-partly no doubt on account of the free use of the Greek character-but if anyone wishes to know the way of life in the Greek archipelago or is to visit Chios, this is the very book for them; and if they are to know the Chians, it is essential.

J. H. HutToN

\section{ON REMOTE HEBRIDEAN ISLANDS}

\section{Island Going}

To the Remoter Isles, chiefly uninhabited, off the North-West Corner of Scotland. By Robert Atkinson. Pp. 384+47 plates. (London and Glasgow: Wm. Collins, Sons and Co., Ltd., 1949.) 16s. net.

THE author of this book, regardless of hardship and discomfort, has lived on North Rona and other outlying Scottish islands, which are now uninhabited. $\mathrm{H}_{\theta}$ has done pioneering ornithological work and made valuable observations; his photographs are admirable. He has done what few naturalists have done-passed a summer night on that lonely bird-haunted rock Sùla Sgeir, forty miles north of the Butt of Lewis. Here he obtained remarkable photographs by flashlight of Leach's petrel in flight and a particularly fine photograph of the gannet colony on the rock.

Mr. Atkinson has observed the guillemots and puffins on the Flannans and has made more than one arduous voyage to St. Kilda to photograph the St. Kilda wren, of which his photographs are perhaps the best in existence. Here is the material for an cutstanding book, and yet the author has just failed to write it. $\mathrm{He}$ writes on occasion vividly enough, but indulges overmuch in mimicry of Hebrideans, their ways, and their English. Yet his own prose is by no means above reproach, and when reading I have sometimes found myself wondering what he really means. $\mathrm{He}$ writes, for example, of the engine of his boat "beating its oily guts"; he likes to speak of the "unwarm" air. His descriptions, too, of birds are sometimes strange. Thus, on p. 38 he writes of "Boar and Sow Guillemot" and, on p. 176, of "gross and squaking terns".

Yet there is much of value in the book, and the author has been at considerable pains to collect, and often to quote, an exhaustive bibliography on the little-known islands he has visited. $\mathrm{He}$ estimates (p. 70) that there is a nesting colony of 380 pairs of Leach's petrel on North Rona, and writes of the great slaughter on that island of puffins, kittiwakes and other sea birds by greater black-backed gulls. On p. 84 he records the strange fact that the egg of Leach's petrel may be left unincubated for several days, and yet it apparently hatches out successfully. $\mathrm{He}$ is right in saying that the stormy petrels, and not the terns, merit the name "sea swallows". Their swallow-like flight is apparent to all who have studied them. Leach's fork-tailed petrel is rather larger than the common stormy petrel, and is not so late in laying its eggs. It is found on very few islands-St. Kilda group, North Rona, Sùla Sgeir and the Flannansand Mr. Atkinson has studied them at all these places with great enthusiasm.

$\mathrm{He}$ has something to say of the killing of the young gannets on Sùla Sgeir for food. This harvesting of the young birds was at one time usual at most of their breeding rocks. They were taken on the Bass, Ailsa Craig, the St. Kilda stacks and on Sula Sgeir.
They are now taken only on one rock, namely, Sùla Sgeir, where the fledglings are known as gugas. It was news to me that, besides being eaten with relish on Lewis (the crew of the boat making the expedition sails from Port of Ness in Lewis), they are salted and dressed and sent by post to Lewismen throughout the world.

Besides his visits to outlying isles, the author stayed on the Inner Hebridean island of Eigg, to study the shearwaters there; his visit to Canna for the same purpose was without success. But his first love is North Rona, and it is evident that he is most happy when he is ashore on that island. He records the crash-landing of an aeroplane there during the Second World War. I recall hearing of this at the time, and wondering how it had been possible to rescue the crew on an isle continually pounded in winter by heavy seas-that was before the time when helicopters were used for rescue work.

It is, by the way ( $p, 178$ ), the cry of the great northern diver and not the red-throated diver that is said to foretell winds and rain. Seton Gordon

\section{PRINCIPLES OF SOIL IRRIGATION}

\section{Irrigated Soils}

Their Fertility and Management. By Prof. D. W. Thorne and Prof. H. B. Peterson. Pp. ix +288. (Philadelphia and Toronto : The Blakiston Company, 1949.) 5 dollars.

7 HERE are probably between 250 to 300 million acres under irrigated agriculture in the world, China, India and Pakistan accounting for about half the total. Plans for bringing another forty to fifty million acres under irrigation, including twenty-five million in India and Pakistan, have been projected. This huge area includes much of the most productive land in the world. It is estimated that more than half the population of the world depends on food grown under irrigation; but, in spite of the great and growing importance of irrigation for food production, very few authoritative text-books on irrigated agriculture have appeared.

The book here under review is an extremely valuable addition to the literature. It deals, as its title indicates, with irrigated soils; but all the unique characteristics of irrigated agriculture derive from the application of water to the soil and the high degree of control that can thereby be obtained over the effective climate for plant growth. Treatment of the subject is comprehensive, and includes a short account of the history and present extent of irrigation, the nature and problems of arid soils, soil and water in relation to plant growth, the quality, measurement and application of irrigation water, drainage, and the management and manuring of the land under all the important irrigated crops. The conditions described are those of the United States, and most of the research work cited is American; but such a wide range of irrigated conditions from extreme aridity to sub-humidity is found, and so much thorough research has been done, in the United States that the great store of information provided will be applicable everywhere that irrigation is practised.

The authors begin by describing and explaining the basic principles which underlie soil-management practices, and then illustrate the application of the principles to the solution of the many problems that arise from irrigation. For the soil chemist and 